\title{
Adipose-derived stem cells (ADSC) in the viability of a random pattern dorsal skin flap in rats ${ }^{1}$
}

\author{
Caio Vinicius Suartz', Silvana Gaiba ${ }^{\text {II }}$, Jerônimo Pereira de França ${ }^{\text {III }}$, Antonio Carlos Aloise ${ }^{\mathrm{II}}$, Lydia Masako Ferreira ${ }^{\mathrm{IV}}$ \\ DOI: http://dx.doi.org/10.1590/S0102-86502014001700001 \\ IGraduate Student, Department of Surgery Federal University of São Paulo, São Paulo, SP, Brazil. Technical procedures. \\ IIPhD Plastic Surgery Division, Department of Surgery Federal University of Sao Paulo, São Paulo, SP, Brazil. Technical procedures, acquisition and \\ interpretation of data, manuscript writing. \\ IIIPhD, Associate Professor, Department of Biological Sciences, Universidade Estadual de Santa Cruz, Ilhéus-BA, Brazil. Interpretation of data and \\ critical revision.

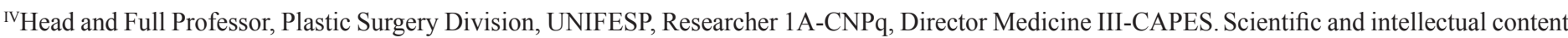 \\ of the study, interpretation of data and critical revision.
}

\begin{abstract}
PURPOSE: To evaluate the viability of random pattern dorsal skin flaps in rats after injection of adipose-derived stem cells (ADSC).

METHODS: Thirty five adult male Wistar EPM rats (weight 250-300 g) were distributed, at random, in two groups. I- Control (flap elevation with injection of saline solution) with fifteen animals and II- Experimental (flap elevation with injection of ADSC ) with fifteen animal. The ADSC were isolated from others five adult male rats. A dorsal skin flap measuring 10x4 $\mathrm{cm}$ was raised and a plastic barrier was placed between the flap and its bed in both groups and the injection (cells or saline solution) were perfomed immediately after the surgery. The percentage of flap necrosis was measured on the seventh postoperative day.

RESULTS: The ADSC were able to replicate in our culture conditions. We also induced their adipogenic, osteogenic and chondrogenic differentiation to verify their mesenchymal stem cells potentiality in vitro. The results were statistically significant showing that the ADSC decreased the area of necrosis $(\mathrm{p}<0.05)$.

CONCLUSIONS: The cells demonstrated adipogenic, osteogenic and chondrogenic differentiation potential in vitro. The administration of adipose-derived stem cells was effective to increase the viability of the random random pattern dorsal skin flaps in rats.
\end{abstract}

Key words: Surgical Flaps; Rats; Adult Stem Cells; Stem Cells; Adipose Tissue 


\section{Introduction}

The stem cells are characterized by their undifferentiated state and their ability generate new stem cells and specialized cells with possible different functions. Stem cells can be embryonic or adult ${ }^{1}$, the mesenchymal adult stem cells derived from human tissues like bone marrow and adipose tissue and are considerate pluripotent cells and can differentiate into others cell types: osteocytes, chondrocytes, adipocytes, muscle cells, neural and angiogenic cells ${ }^{1,2}$.

The beginning of the study of stem cells occurred to the researchers Ernest McCulloch and James Till at the Ontario Cancer Institute in Toronto. Their research reported on the presence of self-renewing cells in bone marrow of mice, and these cells were postulated as regenerative stem cells $\mathrm{s}^{3,4}$.

In 2001 stem cells derived from adipose tissue (ADSC) were added to the group of adult stem cells, showing that they are able to differentiate into mesodermal cells (adipocytes, chondrocytes, osteocytes, and myocytes) ${ }^{1}$.

Nowadays, it is known that the ADSCs have the ability to form consistent cells as neurons ${ }^{5}$, Oligodendrocytes ${ }^{6}$, Schwann cells ${ }^{7,8}$ and epidermal cell lineage ${ }^{9}$.

The clinical use of this cell type may vary from angiogenesis and neurogenesis stimulation in spinal cord injury ${ }^{10}$ to the suppression of the inflammatory response, oxidative stress, and apoptosis in rodent models of ischemia and reperfusion ${ }^{11}$.

The partial necrosis of the skin flaps remains a significant problem in plastic surgery. Recent studies on addition of stem cells from adipose tissue in subcutaneous tissue of rats demonstrate increased vascularity and viability of skin flaps ${ }^{12,13}$. But, these studies have not compared others forms of cell administration. The aim of this study was to evaluate the effects of adipose-derived stem cells on the viability of random skin flap in rats.

\section{Methods}

This project was approved by the Ethics Committee of

\section{UNIFESP.}

Thirty five adult male Wistar EPM rats (weight 250 $300 \mathrm{~g}$ ) were distributed, at random, in two groups. I- Control (flap elevation with injection of saline solution) with fifteen animals and II- Experimental (flap elevation with injection of ADSC ) with fifteen animal.

All animals were anesthetized with an intraperitoneal injection of $60 \mathrm{mg} / \mathrm{kg}$ of ketamine and $5 \mathrm{mg} / \mathrm{kg}$ xylazine. The dorsal random pattern dorsal skin flaps in rats, measuring $10 \mathrm{X} 4 \mathrm{~cm}$, following experimental model proposed by MCFarlane et al. ${ }^{14}$ was raised from the deep fascia, including the superficial fascia, panniculus carnosus, subcutaneous tissue, and skin. After flap elevation, a plastic barrier (polyester/polyethylene), with the same flap dimensions $(10 \mathrm{X} 4 \mathrm{~cm})$ was placed between the skin flap and its bed, after that, the flap was sutured back in place with simple 4-0 nylon sutures. Subsequently, 5X106 ADSC in PBS $(0.5 \mathrm{~mL})$ were slowly injected into the caudal vein over 3 minutes using an insulin syringe in the group experimental. Control group of animals received only $0.5 \mathrm{~mL}$ of PBS.

\section{Macroscopic analysis of necrosis percentages}

The percentage of skin flap necrosis was measured on the seventh postoperative day, using the paper template method described by Sasaki and Pang ${ }^{15}$. After anesthesia, each flap's limit between viable skin and necrosis was delineated with a pen. The viable tissue limit has been characterized by soft skin, pink, warm and haired, and necrotic tissue by stiff, dark cool, and hairless skin.

\section{Isolation, culture and expansion of ADSC}

ADSC were isolated from adult male Wistar EPM rats (weight $250-300 \mathrm{~g}, \mathrm{n}=5$ ). Rat adipose tissue from inguinal region was enzymatically dissociated for $30 \mathrm{~min}$ at $37{ }^{\circ} \mathrm{C}$ by 0.1 $\%(w / v)$ collagenase type I (Sigma-Aldrich). After centrifugation, the stromal cell pellet was resuspended in Dulbecco's Modified Eagle's Medium/Nutrient Mixture F-12 Ham (DMEM/F12) (Sigma-Aldrich) supplemented with 10\% Fetal Bovine Serum (FBS) (Cultilab, Campinas-SP, Brazil), $100 \mathrm{U} / \mathrm{ml}$ penicillin (SigmaAldrich) and $0.1 \mathrm{mg} / \mathrm{ml}$ streptomycin (Sigma-Aldrich). The culture was maintained at $37^{\circ} \mathrm{C}$ in humidified atmosphere of $95 \% \mathrm{O} 2$ and $5 \% \mathrm{CO} 2$ and passages with trypsin/EDTA (Gibco) when required. Cells at passage 3 or below were used for experimentation.

\section{Differentiation assays}

Differentiation assays was done according to the method described by Gaiba et al. ${ }^{16}$. Osteogenic, adipogenic and chondrogenic differentiation were performed to determine multipotenciality of isolated cells. The cells were cultured in differentiation media for 21 days. After this period, the cultures were stained by a solution of Alizarin, Oil Red $\mathrm{O}$ and Toluidine Blue for osteogenic, adipogenic and chondrogenic differentiation, respectively. The fixed and dyed cells were observed using Nikon Ti-U optical microscope and photographed using the NISElements - 3.2 Software (Nikon Instruments INC, New York). 


\section{Statistical analysis}

The results are expressed as mean $\pm \mathrm{SD}$. Comparison between two means was performed by unpaired Student's t-test. All data were analyzed using GraphPad Prism 3.0 software. Statistically significance was accepted when $\mathrm{P}<0.05$.

\section{Results}

\section{Macroscopic analysis of necrosis percentages}

The regions of survival and necrosis were clearly demarcated in every flap at 7 th day post operation. Figure 1 presents means and distribution of data obtained for percentages of flap viability in the groups. The percentages of viability area (mean \pm standard deviation) in the ADSC and control groups were $(58.14 \pm 4.460) \%$ and $(38.86 \pm 5.021) \%$, respectively.

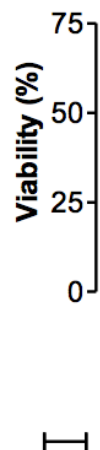

FIGURE 1 - Distribution of the percentage of viability area of the groups. These values were analyzed using unpaired Student's $t$ test and statistical significance was obtained $(\mathrm{p}<0.05)$.

\section{Isolation, culture and expansion of ADSC}

Upon applying multilineage differentiation (adipogenic, osteogeneic and chondrogenic) the cells showed accumulated intracellular lipid droplets as revealed by Oil Red O staining (Figure 2A) and displayed extracellular calcium precipitates, which were identified by Alizarin red staining (Figure 2B) and
Chondrogenic differentiation demonstrated by Toluidin blue stain (Figure 2C). Indicates that these cells can differentiate into adipocytes, osteoblasts and chondroblasts.

\section{Discussion}

The use of ADSCs, which are capable to differentiate into mesodermal cells, it has been possible since 2001'. Their applicability in experimental models has increased and can be used in the future application in humans ${ }^{17}$.

The use of ADSCs in plastic surgery has also been studied and increasingly used, for example, to increase the success rate of grafts viability ${ }^{18}$ as well as small defects in fat grafting ${ }^{19}$. Studies have been done in rats comparing qualitatively peritoneal and inguinal region tissues ${ }^{19}$, however there are no studies that compare quantitatively the number of ADSC in these regions.

The peritoneal fat, have lower gain of adipose tissue mass compared to lower regions of the body, as the inguinal region, due to a protective mechanism that aims to reduce the metabolic consequences of weight gain ${ }^{20}$. The statistically significant results comparing both collected areas directs the ADSC extraction from the inguinal region, ensuring greater concentration of cells collected in comparision to the peritoneal region, which in turn can be useful in designing future studies aimed at testing the properties of ADSC, as done in this work, which envisaged its closest application to clinical practice.

Regarding the clinical applicability of stem cells, the cutaneous flap is a common and valuable procedure in plastic surgery, such as the repair of retractions of burns and reconstructions after oncologic resections. However, there are factors such as ischemia and necrosis, which may damage its development, justifying the need to investigate possibilities to reduce these risks and increase the viability of the flap ${ }^{21-25}$.

Studies with models of grafts $^{26}$, and flaps ${ }^{27}$ using the inguinal region ADSC showed increased viability of the necrotic area, however the route of administration of ADSC was

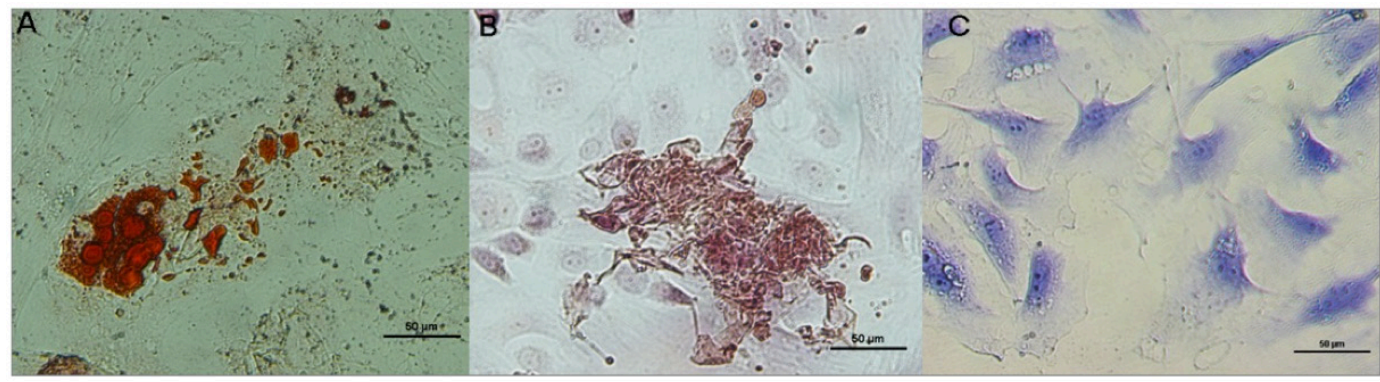

FIGURE 2 - Multilineage differentiation. ADSC are typical fibroblast-like cells with fusiform shape. (A) Adipogenic differentiation demonstrated by Oil Red O staining after 21 days (positive intracellular lipid droplets). (B) Osteogenic differentiation demonstrated by Alizarin red stain after 21 days induction (positive staining of calcium nodule formation). (C) Chondrogenic differentiation demonstrated by Toluidin blue stain 21 days induction. 
subcutaneously. In the present study, the route of administration was intravenous, finding similar results to those mentioned, which show an increase in flap viability with the use of ADSC.

The statistically significant results regarding the use of ADSC from the inguinal region, decreasing skin flap necrosis, contribute to approximate the experimental use to clinical practice. However, further studies are needed to complement these results, such as the realization of immunohistochemical markers seeking whether there is an increased local vascularization of the flap and the presence of stem cells applied in the flap area.

\section{Conclusions}

The studied cells (ADSCs) demonstrated adipogenic, osteogenic and chondrogenic differentiation potential in vitro. The intravenous administration of adipose-derived stem cells was effective to increase the viability of the random pattern dorsal skin flaps in rats.

\section{References}

1. Zuk PA, Zhu M, Mizuno H, Huang J, Futrell JW, Katz AJ, Benhaim P, Lorenz HP, Hedrick MH. Multilineage cells from human adipose tissue: implications for cell-based therapies. Tissue Eng. 2001 Apr;7(2):211-28. doi: 10.1089/107632701300062859

2. Planat-Benard V, Silvestre JS, Cousin B, André M, Nibbelink M, Tamarat R, Clergue M, Manneville C, Saillan-Barreau C, Duriez M, Tedgui A, Levy B, Pénicaud L, Casteilla L. Plasticity of human adipose lineage cells toward endothelial cells: physiological and therapeutic perspectives. Circulation. 2004 Feb 10;109(5):656-63. doi: 10.1161/ 01.CIR.0000114522.38265.61

3. Becker AJ, McCulloch EA, Till JE. Cytological demonstration of the clonal nature of spleen colonies derived from transplanted mouse marrow cells. Nature. 1963 Feb 2;197:452-4. doi: 10.1038/197452a0

4. Zhang J, Shehabeldin A, da Cruz LA, Butler J, Somani AK, McGavin M, Kozieradzki I, dos Santos AO, Nagy A, Grinstein S, Penninger JM, Siminovitch KA. Antigen receptor-induced activation and cytoskeletal rearrangement are impaired in WiskottAldrich syndrome protein-deficient lymphocytes. J Exp Med. 1999 Nov 1;190(9):1329-42. doi: 10.1084/jem.190.9.1329

5. Kang SK, Putnam LA, Ylostalo J, Popescu IR, Dufour J, Belousov A, Bunnell BA. Neurogenesis of Rhesus adipose stromal cells. J Cell Sci. 2004 Aug 15;117(Pt 18):4289-99. doi: 10.1242/jcs.01264

6. Safford KM, Safford SD, Gimble JM, Shetty AK, Rice HE. Characterization of neuronal/glial differentiation of murine adiposederived adult stromal cells. Exp Neurol. 2004 Jun;187(2):319-28. doi: 10.1016/j.expneurol.2004.01.027

7. Kingham PJ, Kalbermatten DF, Mahay D, Armstrong SJ, Wiberg M, Terenghi G. Adipose-derived stem cells differentiate into a Schwann cell phenotype and promote neurite outgrowth in vitro. Exp Neurol. 2007 Oct;207(2):267-74. doi: 10.1016/j.expneurol.2007.06.029

8. Xu Y, Liu L, Li Y, Zhou C, Xiong F, Liu Z, Gu R, Hou X, Zhang C. Myelin-forming ability of Schwann cell-like cells induced from rat adipose-derived stem cells in vitro. Brain Res. 2008 Nov 6;1239:4955 doi: 10.1016/j.brainres.2008.08.088

9. Trottier V, Marceau-Fortier G, Germain L, Vincent C, Fradette J.
IFATS collection: Using human adipose-derived stem/stromal cells for the production of new skin substitutes. Stem Cells. 2008 Oct;26(10):2713-23. doi: 10.1634/stemcells.2008-0031

10. Oh JS, Park IS, Kim KN, Yoon DH, Kim SH, Ha Y. Transplantation of an adipose stem cell cluster in a spinal cord injury. Neuroreport. 2012 Mar 28;23(5):277-82. doi: 10.1097/WNR.0b013e3283505ae2

11. Reichenberger MA, Heimer S, Schaefer A, Lass U, Gebhard MM, Germann G, Leimer U, Köllensperger E, Mueller W. Adipose derived stem cells protect skin flaps against ischemia-reperfusion injury. Stem Cell Rev. 2012 Sep;8(3):854-62. doi: 10.1007/s12015012-9368-5

12. Yang M, Sheng L, Li H, Weng R, Li QF. Improvement of the skin flap survival with the bone marrow-derived mononuclear cells transplantation in a rat model. Microsurgery. 2010 May;30(4):27581. doi: $10.1002 /$ micr. 20779

13. Lee DW, Jeon YR, Cho EJ, Kang JH, Lew DH. Optimal administration routes for adipose-derived stem cells therapy in ischaemic flaps. J Tissue Eng Regen Med. 2012 Jul 10. doi: 10.1002/ term.1552. Epub 2012 Jul 10

14. MCFarlane RM, Deyoung G, Henry RA. The design of a pedicle flap in the rat to study necrosis and its prevention. Plast Reconstr Surg. 1965 Feb;35:177-82. PMID: 14264468

15. Sasaki GH, Pang CY. Hemodynamics and viability of acute neurovascular island skin flaps in rats. Plast Reconstr Surg. 1980 Feb;65(2):152-8. PMID: 7352155

16. Gaiba S, França LP, França JP, Ferreira LM. Characterization of human adipose-derived stem cells. Acta Cir Bras. 2012 Jul;27(7):471-6. doi: 10.1590/S0102-86502012000700007

17. Wei X, Yang X, Han ZP, Qu FF, Shao L, Shi YF. Mesenchymal stem cells: a new trend for cell therapy. Acta Pharmacol Sin. 2013 Jun;34(6):747-54. doi: 10.1038/aps.2013.50

18. Beahm EK, Walton RL, Patrick CW Jr. Progress in adipose tissue construct development. Clin Plast Surg. 2003 Oct;30(4):547-58. PMID: 14621302

19. DiGirolamo M, Fine JB, Tagra K, Rossmanith R. Qualitative regional differences in adipose tissue growth and cellularity in male Wistar rats fed ad libitum. Am J Physiol. 1998 May;274(5 Pt 2):R1460-7. PMID: 9612415

20. Tchoukalova YD, Koutsari C, Votruba SB, Tchkonia T, Giorgadze N, Thomou T, Kirkland JL, Jensen MD. Sex- and depot-dependent differences in adipogenesis in normal-weight humans. Obesity (Silver Spring). 2010 Oct;18(10):1875-80. doi: 10.1038/oby.2010.56

21. Harder Y, Amon M, Erni D, Menger MD. Evolution of ischemic tissue injury in a random pattern flap: a new mouse model using intravital microscopy. J Surg Res. 2004 Oct;121(2):197-205. PMID: 15501459

22. Abla LE, Gomes HC, Percario S, Ferreira LM. Acetylcysteine in random skin flap in rats. Acta Cir Bras. 2005 Mar-Apr;20(2):121-3. doi: 10.1590/S0102-86502005000100004

23. Liebano RE, Abla LE, Ferreira LM. Effect of low-frequency transcutaneous electrical nerve stimulation (TENS) on the viability of ischemic skin flaps in the rat: an amplitude study. Wound Repair Regen. 2008 Jan-Feb;16(1):65-9. doi: 10.1111/j.1524475X.2007.00332.X

24. Tacani PM, Liebano RE, Pinfildi CE, Gomes HC, Arias VE, Ferreira LM. Mechanical stimulation improves survival in random-pattern skin flaps in rats. Ultrasound Med Biol. 2010 Dec;36(12):2048-56. doi: 10.1016/j.ultrasmedbio.2010.07.020

25. Nishioka MA, Pinfildi CE, Sheliga TR, Arias VE, Gomes HC, Ferreira LM. LED $(660 \mathrm{~nm})$ and laser $(670 \mathrm{~nm})$ use on skin flap viability: angiogenesis and mast cells on transition line. Lasers Med Sci. 2012 Sep;27(5):1045-50. doi: 10.1007/s10103-011-1042-7 
26. Zografou A, Papadopoulos O, Tsigris C, Kavantzas N, Michalopoulos E, Chatzistamatiou T, Papassavas A, StavropoulouGioka C, Dontas I, Perrea D. Autologous transplantation of adiposederived stem cells enhances skin graft survival and wound healing in diabetic rats. Ann Plast Surg. 2013 Aug;71(2):225-32. doi: 10.1097/ SAP.0b013e31826af01a

27. Yue Y, Zhang P, Liu D, Yang JF, Nie C, Yang D. Hypoxia preconditioning enhances the viability of ADSCs to increase the survival rate of ischemic skin flaps in rats. Aesthetic Plast Surg. 2013 Feb;37(1):159-70. doi: 10.1007/s00266-012-9993-z

\section{Correspondence:}

Lydia Masako Ferreira

Disciplina de Cirurgia Plástica, Departamento de Cirurgia

Universidade Federal de Sao Paulo

Rua Napoleão de Barros, $715 / 4^{\circ}$ andar

04042-002 Sao Paulo - SP Brasil

Tel.: (55 11)5576-4118

Fax: (55 11)5571-6579

sandcir@hotmail.com

silvanagaiba@gmail.com

Conflict of interest: none

Financial sources: CAPES and CNPq (n 312356/2009-9)

${ }^{1}$ Research performed at Plastic Surgery Division, Federal University of Sao Paulo (UNIFESP), Brazil. 